\title{
CLIMATE CHANGE AND ENERGY SECURITY
}

Cong Thuy Duong, Doan Thu Dung, Phan Thuy Duong, Nguyen Tan Dung, Hoang Thi Hong Chuc, Hoang Thi Linh Chi, Vu Quynh Chi, Nguyen Hoang Chi, Nguyen Cam Duong, Le Thi Thanh Diem.

\author{
Vietnam National University, Hanoi \\ Hanoi, January 20, 2022 \\ Preprint DOI: 10.31219/osf.io/9sejb
}

Protecting the green - clean - beautiful living environment is a matter of concern for the whole world. There are many global or regional conferences held to discuss and find a way to solve that problem. In which, climate change, energy depletion and greenhouse effect are hot issues, this is one of the great challenges for all mankind because they are directly affecting ecology. environment and human life.

The forest fire in Greece in August 2021 is said to be one of the hot events on this issue. According to Greek Prime Minister Kyriakos Mitsotakis, this is the country's worst environmental disaster. From August 3 to August 12, the biggest fire on the island of Evia (the country's second largest island) devastated much of the northern part of the island. The fire claimed 3 lives and destroyed nearly 100,000 hectares of forest and agricultural land. IAccording to the World Meteorological Organization (WMO), wildfires are part of a trend of extreme weather events caused by human-caused climate change. 


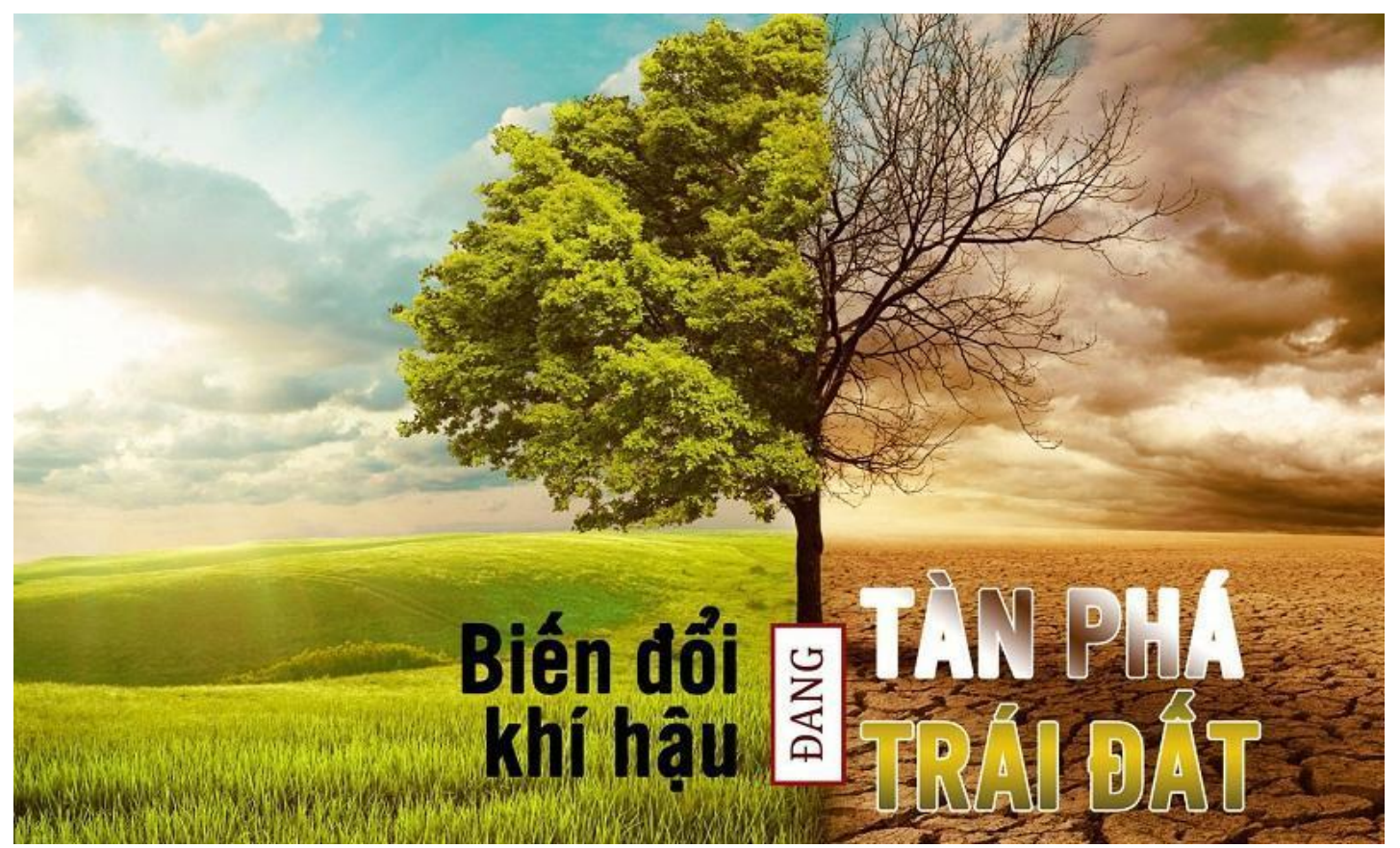

Fig.1. An illustration of how climate change is ravaging the earth Source: https://khbvptr.vn/bien-doi-khi-hau-la-gi/

Climate change, in addition to causing a number of impacts, also poses many threats to human rights. Climate change is affecting people more and more clearly, with prolonged natural disasters, droughts and floods causing crop failures and food shortages; Pollution of soil, water, air... directly affects human health(H. T. H. Hanh, 2022; N. T. Hanh, 2022; Van Khuc et al., 2020; Q. Vuong et al., 2021) ; Landslides and landslides cause people to lose their homes and even their lives. These actions have directly infringed on the human right to life (Huyền, 2016) .But Vietnam and the world are still struggling to face climate change. During the COP26 conference, Vietnam made a number of commitments as well as some effective and constructive actions in combating global climate change. Vietnam has also announced action plans and initiatives to tackle climate change, including the National Climate Change Strategy, the Paris Agreement Implementation Plan and the Emissions Management Scheme, greenhouse gas emissions and the National Plan on Climate Change Adaptation for the period 2021-2030, with a target to 2050. It also regulates issues related to response to climate change, such as law on disaster prevention, law on environmental protection, law on water resources, etc (Nhâm, 2021).

The world mentioned 7 initiatives to reduce climate change: invest heavily in clean energy; US - China act against climate change; Africa climate week spurred regional action; COP26 host country "reminds" donors; transform the 
global food system; youth action on climate change; pre-COP26 conference (Thanh, 2021). Vietnam and the world have been and will always make efforts in mitigating the impact of climate change on human life (Khuc, 2022).

In addition to climate change, the problem of energy depletion is also at an alarming rate that is no longer a worry in the distant future, the situation of energy depletion is gradually being demonstrated by events occurring in the future. out in reality. At the beginning of this year, a long and unusually cold European winter drained gas reserves, and, due to the impact of a series of storms, in the Gulf oil refineries were forced to close. The economic recovery after the COVID-19 pandemic led to increased energy demand (B. Anh, 2021). In Vietnam, there is a serious imbalance between electricity development and economic development, stemming from the loss and waste of energy sources, and the low efficiency of electricity use.
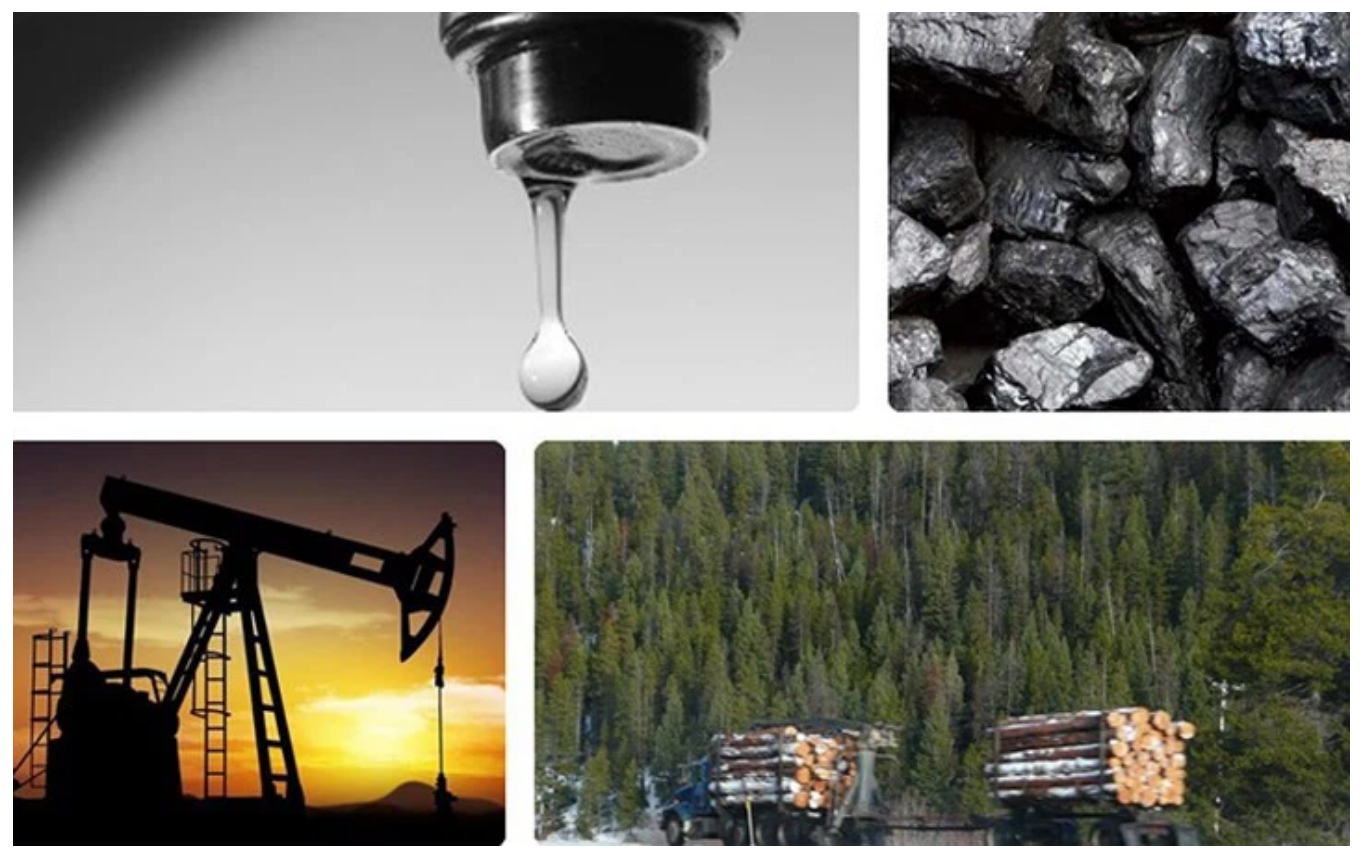

Fig.2. Illustration for the depletion of energy resources in the world

Source:

https://cafef.vn/nhung-tai-nguyen-thien-nhien-hang-dau-se-som-can-kiet-201809201402 08993.chn

While five 70 of the twentieth century, to deal with the problem of depletion of fossil energy resources, many countries aim to use nuclear energy as an alternative. However, only about 10 years later, in the 1980s, the world witnessed the failure of this plan. The reason lies in the safety problems of 
nuclear power plants, which have many limitations: radioactive leaks, nuclear accidents, radioactive contamination of people, etc (Trân, 2007).

However, now we have many reasonable policies to improve the situation. In Vietnam, on February 11, 2020, the Politburo issued Resolution No. 55 $\mathrm{NQ} / \mathrm{TW}$ on the orientation of our country's national energy development strategy to 2030, with a vision to 2045. According to some estimates, about 16 million tons of oil equivalent to about 103.7 billion $\mathrm{kWh}$ of electricity will be saved compared to energy demand for socio-economic development if this Target Program is implemented (Bình, 2021). As of July 2020, in terms of renewable energy sources, the national power system has a total of 99 operating solar power plants, of which the total capacity is 5,053 MW. At the same time, the total capacity of 11 wind power plants in operation is $429 \mathrm{MW}$, including $325 \mathrm{MW}$ of biomass power along with nearly $10 \mathrm{MW}$ of solid waste electricity. It can be seen that the total capacity of wind and solar power is 5,482 MW, accounting for about $9.5 \%$ of the total installed source capacity of the system. Not stopping there, in terms of rooftop solar power, there were over 47,000 systems installed with a total capacity of 1,128 MWp, as of August 2020 (Hưng, 2020).

Around the world, many countries have been promoting the use of renewable energy sources. It can be seen that Côte d'Ivoire (in West Africa) produces about 2,000 MW of electricity per year, of which thermal power accounts for $75 \%$ and the rest is hydroelectric. Besides, renewable energy increasing the proportion to $11 \%$ of total electricity by 2020 and up to $16 \%$ by 2030 is the main goal of this country (M. Anh, 2019). In addition, we cannot fail to mention the European Union Summit on energy issues. The European Union (EU) has urged countries to urgently use a "toolbox" to support the most vulnerable consumers and European companies in the short term . (Quyên, 2021).

In addition to the two hot issues mentioned above, the greenhouse effect is also an extremely urgent topic because it is one of the most painful consequences of global climate change. As greenhouse gas concentrations increase, so does the average global surface temperature. As a result, extreme weather events have become more common across the planet. (In 2020, severe drought hit various areas of the South American continent, In addition, the North Atlantic region experienced an unusually intense rainy season, with 30 tropical cyclones, breaking 2005's hurricane season record) 
(DWRM, 2020). Rising global temperatures also lead to the melting of Greenland, Antarctica and glaciers around the world and cause sea levels to riseGlobally, sea levels have risen on average $3.29(+/-0.3) \mathrm{mm}$ per year, and peaked in 2020. (N. R. Claire Ransom, 2020).

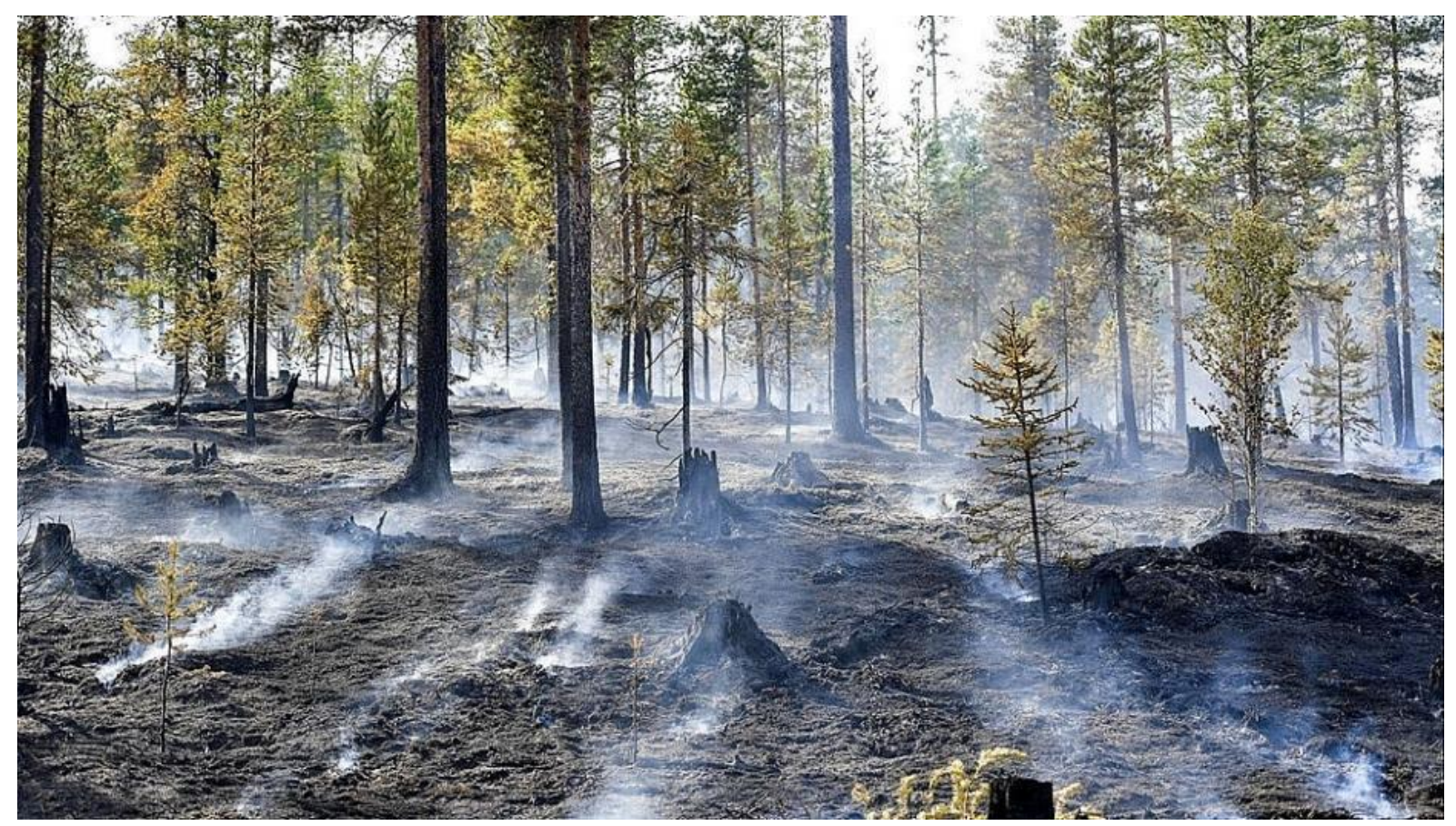

Fig.3. Consequences of the greenhouse effect

Source:

https://kinhtemoitruong.vn/hieu-ung-nha-kinh-va-nhung-hau-qua-kho-luong-8820 .html

In response to the increasingly alarming situation of the greenhouse effect, environmental organizations have actively participated in conferences to come up with agreements and solutions to improve this climate phenomenon. However, many of those efforts have failed. The 2015 Paris Agreement set a goal of keeping the Earth's temperature below $1.5^{\circ} \mathrm{C}$, but it was not successful because the parties involved were difficult to realize that goal. Based on the content of the sixth report (AR6) of the Intergovernmental Panel on Climate Change (IPCC) emphasized that: "Some changes, such as limiting sea level rise, are not can take hundreds or thousands of years". According to climate and energy experts from Sweden, Norway and Austria, achieving the goal of limiting the Earth's temperature rise to more than $1.5^{\circ} \mathrm{C}$ will require significant reductions in 
energy use, something that any economy in the world can hardly bear (BBT, 2021).

The greenhouse effect increases existing risks and exacerbates factors that can lead to conflict and insecurity. For example, the impact of greenhouse gases on agriculture and pastoralism with ethnic political factors in Sudan have contributed to the escalation of violent tensions in Darfur and made conflict resolution difficult. should be more difficult. In Syria and Iraq, the radical group Daesh exploits the growing competition for weaponized water and natural resources by controlling access to and diversion of rivers. In addition, extreme weather events in Central America and the Caribbean have devastated critical infrastructure and forced people to relocate, and in some places even impacted crime rates. This number increased dramatically. (R. DiCarlo, 2020)

On a global scale, the United Nations has made many efforts in the fight against the greenhouse effect. Some remarkable achievements have been achieved such as the United Nations Framework Convention on Climate Change (UNFCCC) - which came into force on March 19, 1994 with the goal of achieving stabilization of greenhouse gases in the atmosphere. At a level that would prevent dangerous anthropogenic interference with the climate system, the Kyoto Protocol (KP) - entered into force on December 16, 2005 to assist developing countries in implementing sustainable development and developed countries making commitments to reduce greenhouse gas emissions (MET, 2018). Well aware of the impact of the greenhouse effect, Vietnam has also soon participated in regional and international response activities on greenhouse effects as well as climate change such as: Joining the United Nations Framework Convention on climate change (UNFCCC); signed the Kyoto Protocol (KP); passed the Law on Economical and Efficient Use of Energy...; implementing programs and projects directly related to greenhouse gas emission reduction: National target program on economical and efficient use of energy; National action program on reducing greenhouse gas emissions through efforts to limit deforestation and forest degradation, sustainable management of forest resources,...(Vihema, 2020).

To tackle the problems and challenges aformentioned, a number of solutions should be prioritized in the coming time. 
Firstly, strengthening the transformation of environmental culture from awareness to environmental behavior (Khuc, 2021; Van Khuc et al. al., 2021; QH Vuong, 2021; QH et al. Vuong, 2018),

Secondly, using science and technology, information and communication to improve the quality of solutions (Nguyen \& Vuong, 2021; Q. Vuong, 2020; QH Vuong, 2018); Vuong, Q. H., et al. (2022).

Thirdly, strengthen cooperation to attract the participation of business forces in environmental protection (Q.-H. Vuong, 2021; QH Vuong et al., 2021) to be able to deal with the above problems, returning the green, clean and beautiful inherent to the natural environment.

In short, climate change and energy security are the two most pressing issues confronting humanity in the twenty-first century. Using the 3DMS system and the environmental cultural tower, one could find innovative solutions desired.

\section{References:}

Anh, B. (2021). Thế giới đói năng lượng. Tuổi Trẻ Online. https://tuoitre.vn/the-gioi-doi-nang-luong-20211012084245602.htm

Anh, M. (2019). Đẩy mạnh sử dụng các nguồn năng lượng tái tạo. Báo Nhân Dân. https://nhandan.vn/tin-tuc-the-gioi/ay-manh-su-dung-cac-nguon-nang-luong-tai-ta o-348461/

BBT. (2021). Thất bại trong việc đối phó với biến đổi khí hậu: Thảm họa không thể tránh khỏi trên Trái đất. Sputnik Việt Nam. https://vn.sputniknews.com/20211101/that-bai-trong-viec-doi-pho-voi-bien-doi-khihau-tham-hoa-khong-the-tranh-khoi-tren-trai-dat-12329804.html

Bình, A. (2021). Sử dụng tiết kiệm năng lượng và hiệu quả là nền tảng cho phát triển bền vững. Bộ Công Thương Việt https://moit.gov.vn/tin-tuc/su-dung-nang-luong-tiet-kiem-va-hieu-qua/su-dung-tiet -kiem-nang-luong-va-hieu-qua-la-nen-tang-cho-phat-trien-ben-vung.html

DWRM. (2020). Năm 2020 trở thành một trong ba năm nóng nhất từng được ghi nhận trên Trái Đất. Bộ Tài Nguyen và Môi Trường. http://dwrm.gov.vn/index.php?language=vi\&nv=news\&op=Nhin-ra-The-gioi/Nam2020-tro-thanh-mot-trong-ba-nam-nong-nhat-tung-duoc-ghi-nhan-tren-Trai-Dat-96 00

Hanh, H. T. H. (2022). Nguyên nhân và giải pháp cho vấn đề ô nhiễm và cạn kiệt nguồn nước. OSF Preprints. https://doi.org/10.31219/osf.io/ph2rs

Hanh, N. T. (2022). Thực trạng và giải pháp cho vấn đề ô nhiễm không khí ở Việt Nam. OSF Preprints. https://doi.org/10.31219/osf.io/jrxmd

Hưng, G. (2020). Khai thác, sử dụng hiệu quả các nguồn năng lượng tái tạo. Báo Điện Tử Đảng Cộng Sản Việt https://dangcongsan.vn/khoa-hoc-va-cong-nghe-voi-su-nghiep-cong-nghiep-hoa-hi 
en-dai-hoa-dat-nuoc/diem-nhan-khoa-hoc-va-cong-nghe/khai-thac-su-dung-hieu-q ua-cac-nguon-nang-luong-tai-tao-564429.html

Huong, T. (2021). Hy Lạp đã khống chế được các đám cháy rừng kéo dài 9 ngày qua.

Báo

Tin

Tức.

https://baotintuc.vn/the-gioi/hy-lap-da-khong-che-duoc-cac-dam-chay-rung-keo-dai -9-ngay-qua-20210812103847052.htm

Huyền, A. (2016). Đảm bảo quyền con người trước tác động của biến đổi khí hậu. VOV. https://vovworld.vn/vi-VN/binh-luan/dam-bao-quyen-con-nguoi-truoc-tac-dong-cu a-bien-doi-khi-hau-447287.vov.

Khuc, Q. Van. (2021). Environmental culture thoughts to make a better world for our nature and children. OSF Preprints. https://doi.org/10.31219/osf.io/g5zex

Khuc, Q. Van. (2022). Về khả năng ứng dụng của hệ xử lý thông tin 3D và nguyên lý bán dẫn giá trị trong tìm kiếm giải pháp cho vấn đề ô nhiễm môi trường và biến đổi khí hậu ở Việt Nam. Tạp Chí Kinh Tế và Dự Báo, 1-5. https://kinhtevadubao.vn/ve-kha-nang-ung-dung-cua-he-xu-ly-thong-tin-3d-va-ngu yen-ly-ban-dan-gia-tri-trong-tim-kiem-giai-phap-cho-van-de-o-nhiem-moi-truong-v a-bien-doi-khi-hau-o-viet-nam-20840.html

MET. (2018). Tài liệu hướng dẫn dạy và học về Úng phó với biển đổi khí hậu. http://chinhsach.dmptc.gov.vn:8045/Uploads/Thu vien tai lieu/To chuc NGO/tài_liệu_dạy_và_học_về_Úng_phó_với_biến_đổi_khí_hậu.pdf

N. R. Claire Ransom, V. H. (2020). The State of the Global Climate 2020. World Meteorological

Organization. https://public.wmo.int/en/our-mandate/climate/wmo-statement-state-of-global-clim ate

Nguyen, M.-H., \& Vuong, Q.-H. (2021). Evaluation of the Aichi Biodiversity Targets: the international collaboration trilemma in interdisciplinary research. Pacific Conservation Biology. https://doi.org/10.1071/pc21026

Nhâm, N. (2021). Việt Nam tham gia tích cực, trách nhiệm chống biến đổi khí hậu. Báo Điện Tử Đảng Cộng Sản Việt https://dangcongsan.vn/the-gioi/nhung-van-de-toan-cau/viet-nam-tham-gia-tich-cu c-trach-nhiem-chong-bien-doi-khi-hau-596974.html

Quyên, T. (2021). Hội nghị thượng đỉnh Liên minh châu Âu "nóng" với vấn đề năng lượng. Vietnam

Plus. https://www.vietnamplus.vn/hoi-nghi-thuong-dinh-lien-minh-chau-au-nong-voi-va n-de-nang-luong/748308.vnp

R. DiCarlo. (2020). R. DiCarlo, "Climate change multiplying factors that lead to insecurity for millions, Rosemary DiCarlo tells 'Arria Formula' meeting. Political and Peacebuilding

Affairs. https://dppa.un.org/en/climate-change-multiplying-factors-lead-to-insecurity-millio ns-rosemary-dicarlo-tells-arria-formula.

Thanh, H. (2021). 7 nỗ lực chống biến đổi khí hậu nổi bật trước thềm Hội nghị COP26. Báo Tin

Tức. https://baotintuc.vn/the-gioi/7-no-luc-chong-bien-doi-khi-hau-noi-bat-truoc-them-h oi-nghi-cop26-20211011155850756.htm

Trần, M. T. (2007). Năng lượng từ hyđrô sẽ thay thế dầu khí, nguyên tử. Báo Nhân Dân. https://nhandan.vn/khoa-hoc/nang-luong-tu-hydro-se-thay-the-dau-khi-nguyen-tu434949 
Van Khuc, Q., Pham, L., Tran, M., Nguyen, T., Tran, B. Q., Hoang, T., Ngo, T., \& Tran, T. D. (2021). Understanding vietnamese farmers' perception toward forest importance and perceived willingness-to-participate in redd+ program: A case study in nghe an province. Forests, 12(5), 1-14. https://doi.org/10.3390/f12050521

Van Khuc, Q., Phu, T. V., \& Luu, P. (2020). Dataset on the Hanoian suburbanites' perception and mitigation strategies towards air pollution. Data in Brief, 33, 106414. https://doi.org/10.1016/j.dib.2020.106414

Vihema. (2020). Đóng góp do quốc gia tự quyết định của Việt Nam. https://vihema.gov.vn/wp-content/uploads/2020/10/NDC_VN_Clean_final.pdf

Vuong, Q.-H. (2021). Western monopoly of climate science is creating an eco-deficit culture. Economy, Land \& Climate Insight, 11, 1-9. https://elc-insight.org/western-monopoly-of-climat

Vuong, Q. (2020). From children's literature to sustainability science, and young scientists for a more sustainable Earth From children's literature to sustainability science, and young scientists for a more sustainable Earth. Journal of Sustainability Education, 24(December), 2019-2021.

Vuong, Q. H. (2018). The (ir)rational consideration of the cost of science in transition economies. Hature Hehaviour, 2(1), 5. https://doi.org/10.1038/s41562-017-0281-4

Vuong, Q. H. (2021). The semiconducting principle of monetary and environmental values exchange. Economics and Business Letters, 10(3), 284-290. https://doi.org/10.17811/ebl.10.3.2021.284-290

Vuong, Q. H. et al. (2018). Cultural additivity: behavioural insights from the interaction of Confucianism, Buddhism and Taoism in folktales. Palgrave Communications, 4(143). https://doi.org/10.1057/s41599-018-0189-2

Vuong, Q. H., Ho, M. T., Nguyen, M. H., Pham, T. H., Vuong, T. T., Khuc, Q., Ho, H. A., \& La, V. P. (2021). On the environment-destructive probabilistic trends: A perceptual and behavioral study on video game players. Technology in Society, 65(February), 101530. https://doi.org/10.1016/j.techsoc.2021.101530

Vuong, Q., Phu, T. V., Le, T. T., \& Khuc, Q. Van. (2021). Exploring Inner-City Residents' and Foreigners' Commitment. Data, 6(39). https://doi.org/10.17632/8sv4j2r9wk.2

Vuong, Q. H., et al. (2022). Covid-19 vaccines production and societal immunization under the serendipity-mindsponge-3D knowledge management theory and conceptual framework. Humanities and Social Sciences Communications, 9, 22. Retrieved from: https://www.nature.com/articles/s41599-022-01034-6 